\title{
El Niño modifies nutrient status in oil palm and helps foliage to recover from yellowing symptoms: new analysis and perspectives
}

\author{
Bernard Dubos ${ }^{1,2, *}$ (1) and Marcel de Raïssac ${ }^{3,4}$ \\ ${ }^{1}$ CIRAD, UMR ABSys, 34398 Montpellier, France \\ 2 ABSys, Univ Montpellier, CIHEAM-IAMM, CIRAD, INRAE, Institut Agro, Montpellier, France \\ ${ }^{3}$ CIRAD, UMR AGAP, 34398 Montpellier, France \\ 4 AGAP, Univ Montpellier, CIRAD, INRAE, Institut Agro, Montpellier, France
}

\begin{abstract}
In Ecuador, oil palm plantations from the Quinindé-Quevedo region are subject to El Niño/ Southern Oscillation (ENSO) with a preponderance of La Niña weather conditions. With more than $2,000 \mathrm{~mm}$, the total annual rainfall is theoretically non-limiting but, with only $1,000 \mathrm{~h}$, the total annual sunshine is well below the $1,800 \mathrm{~h}$ minimum recommended. Starting in the 1970s, the frequent occurrence of frond yellowing symptoms in the region became a recurrent worry for growers, convinced that they were facing the expression of a mineral deficiency. In this study, we used experimental results to examine the actual role of mineral nutrition in yellowing manifestation. We described the effects of two El Niño events (1982/1983 and 1997/1998) on climate variables and analysed their putative consequences on palm physiological functioning that could explain the observed foliage recovery. Our analysis led us to conclude that a direct mineral deficiency was not involved, as the soil reserves for the main nutrients were not to blame. We rejected the most frequently proposed hypothesis, whereby yellowing is caused by magnesium deficiency. Our study revealed the key role played by nitrogen, the best indicator of yellowing. Variations in $\mathrm{N}$ status appear to be linked to the same factors that determine the symptoms and we opted for the hypothesis of physiological disruption generated by low solar radiation levels under normal conditions. The study also reveals the need to consider specific optimum contents for $\mathrm{N}$ and $\mathrm{Mg}$ and to adjust fertilizer recommendations to local climate conditions.
\end{abstract}

Keywords: mineral nutrition / solar radiation / ENSO / nitrogen / vapor pressure deficit

Résumé - El Niño modifie le statut nutritif des palmiers à huile affectés de symptômes de jaunissement : nouvelle analyse et perspectives. En Equateur, les plantations de palmiers à huile de la région Quinindé-Quevedo sont soumises au phénomène El Niño/Oscillation australe (ENSO) avec une prépondérance des conditions climatiques de La Niña. Avec plus de $2000 \mathrm{~mm}$, le total annuel des précipitations est théoriquement non limitant mais, avec seulement $1000 \mathrm{~h}$, l'ensoleillement total annuel est très inférieur au minimum de $1800 \mathrm{~h}$ recommandé. A partir des années 1970, l'apparition fréquente de symptômes de jaunissement des feuilles dans la région est devenue une préoccupation récurrente des planteurs, convaincus d'être confrontés à l'expression d'une déficience minérale. Dans cette étude, nous avons utilisé des résultats expérimentaux pour examiner le rôle réel de la nutrition minérale dans la manifestation du jaunissement. Nous avons décrit les effets de deux occurrences d'El Niño (1982/1983 et 1997/1998) sur les variables climatiques et analysé leurs conséquences supposées sur le fonctionnement physiologique des palmiers qui pourraient expliquer la rémission observée du feuillage. Notre analyse nous a permis de conclure à l'absence d'une déficience minérale directe, les réserves du sol en éléments majeurs n'étant pas en cause. Nous avons rejeté l'hypothèse la plus fréquemment proposée, selon laquelle le jaunissement serait dû à une déficience en magnésium. Notre étude a révélé le rôle clé de l'azote, meilleur indicateur du jaunissement. Les variations du statut azoté semblent être liées aux mêmes facteurs que ceux qui déterminent les symptômes et nous avons opté pour l'hypothèse d'une perturbation physiologique générée par un faible rayonnement solaire en conditions normales. L'étude révèle également la nécessité de retenir des teneurs optimales spécifiques pour $\mathrm{N}$ et $\mathrm{Mg}$ et d'ajuster les recommandations de fertilisation aux conditions climatiques locales.

Mots clés : nutrition minérale / radiation solaire / ENSO / azote / déficit de pression de vapeur d'eau

*Corresponding author: bernard.dubos6@wanadoo.fr 


\section{Introduction}

Oil palm (Elaeis guineensis Jacq.) is the main source of vegetable oils and fats in the world. Crop fertilisation is essential to guarantee a yield close to the crop's potential determined by the regional climate conditions (Corley \& Tinker, 2016) and can represent up to $50 \%$ of production costs. Local soil physical and chemical properties may result in mineral deficiencies, altering the colour and physiological functioning of fronds. Symptoms are visible to a greater or lesser extent depending on the nutrient involved; nitrogen, potassium and magnesium deficiencies are known to cause leaflet yellowing as already described by Fairhurst et al. (2004). Symptom appearance usually leads farmers to apply corrective fertilisation to prevent any loss in bunches, and hence in oil yields. Because of the continuous increase of fertilizer costs, any mistake in deficiency diagnosis can lead to heavy consequences on farmer budget balance.

In Ecuador, the second largest palm oil producer in South America after Colombia, oil palm began to be grown in the early 1950s. However, the planted areas really took off in the 1960 s with the creation of estate plantations, to reach up to 170,000 ha in 2013 (Burgos and Naranjo, 2013). Unlike other producing countries in South America, Ecuador developed most of its plantations on the east coast of the Pacific, where 223,319 ha were registered in 2017, according to the Ministerio de Agricultura y Ganadería et al. (2018). The main region of production, the Quinindé - Santo DomingoQuevedo region, is located in the provinces of Esmeraldas, Santo Domingo de los Tsachillas and Los Ríos. In 2017, these provinces accounted for $68 \%$ of the total area planted in Ecuador and $60 \%$ of the farms. Beside the agro-industrial plantations, smallholders are widely represented, with $51 \%$ of the farms having less than 10 ha and $89 \%$ less than 50 ha, at the national level (Ministerio de Agricultura y Ganadería et al., 2018).

In this region, like in the whole western part of Ecuador, the climate is subject to an irregular low frequency oscillation between a warm (El Niño) and a cold (La Niña) state. El Niño is due to the marked warming of the surface waters near the South American coasts in the second half of the year (Timmermann et al., 1999) and leads to a wetter and sunnier than normal period. Conversely, the frequently cold and dry climate during the second half of the year corresponds to more or less intense episodes of La Niña. Between 1973 and 2013, El Niño occurred in 1982/1983 and in 1997/1998. According to Cai et al. (2014) these alternations will be more frequent in the future.

In the 1970s, foliage yellowing symptoms frequently appeared in oil palm plantations over five years old and spread to most of the oil palm areas, despite regular application of fertilizers (Renard, 1977; Nápoles, 1979). Soon, the hypothesis of a biotic cause was ruled out as well as fungal diseases (Renard, 1977) or damages caused by insects and nematodes (Nápoles, 1979). The symptoms were often considered as being the result of a nutritional deficiency, mostly of magnesium (Van Slobbe, 1988) due to the onset of symptoms at the tip of the leaves. However it was impossible to confirm a mineral deficiency that could be cured by appropriate fertilization.
After collecting information from plantations located in the studied area, we observed that dramatic foliage recoveries occurred during the 1982/1983 and during the 1997/1998 El Niño events (Corrado, 1998). This fact led us to suspect a relationship between local climate change during El Niño, and a change in plant physiological functioning that could explain the disappearance of the yellowing symptoms.

Over the 1982-2009 period, data on climate and plant composition were collected. We revisited this data set in order to re-analyse the origin of yellowing and we finally propose new explanations and hypotheses.

\section{Materials and methods}

\subsection{Soils and climate}

The studied zone is located in the western foothills of the Andes (Supplementary material [SM] 1).

The landscape is moderately undulating with some steeper slopes along rivers. Soils are referred as andosols in the World Reference Base for Soil Resources classification. They derived from volcanic ashes that have been subjected to weathering, which explains their varied textures, generally poor in clays due to leaching. The colloidal fraction has been enriched by amorphous allophane type compounds.

The rainfall, sunshine and temperature data were extracted from the weather stations at Palmeras de los Andes -- PDA (EL 200 station, $79^{\circ} 26^{\prime} \mathrm{W}, 0^{\circ} 13^{\prime} \mathrm{N}$, elevation $130 \mathrm{~m}$ ) and Instituto Nacional de Investigaciones Agropecuarias - INIAP (Pichilingue station, $79^{\circ} 27^{\prime} \mathrm{W}, 1^{\circ} 5^{\prime} \mathrm{S}$, elevation $75 \mathrm{~m}$ ), located near Quinindé and Quevedo respectively. The global radiation data come from a Davis automatic station used by PDA since 2011.

The risk of a water deficit in the second half of the year was assessed using monthly evapotranspiration (ETP) and rainfall data provided by FAO and available on the CLIMWAT 2.0 website. We used data from La Concordia station $\left(79^{\circ} 23^{\prime} \mathrm{W}\right.$, $0^{\circ} 03^{\prime} \mathrm{S}$, elevation $\left.300 \mathrm{~m}\right)$. The maximum available soil water reserve was estimated at $150 \mathrm{~mm}$, a routinely used value in these soils for oil palm, and a simplified water balance model was run to calculate the FTSW (fraction of transpirable soil water), which is the ratio of actual available water to the total available water (Sinclair and Ludlow, 1986).

\subsection{Differential tissue analyses}

In 2008 and 2009, leaflet samples were taken in PDA plantations on adult oil palms growing under uniform soil and planting material conditions, and displaying or not yellowing symptoms. Two sampling methods were used:

- on each palm, central leaflets were sampled on a healthy frond and on a frond displaying yellowing symptoms on at least the apical leaflets;

- healthy leaflets and yellowing leaflets were sampled on fronds displaying yellowing symptoms. Mineral contents between the tissues with and without yellowing were measured and compared.

\subsection{Nutrient status}

Palm composition was assessed by analysing leaflet mineral content as frequently done for major nutrients 
Table 1. Main climate characteristics for Quinindé and Quevedo.

Tableau 1. Principales caractéristiques climatiques à Quinindé et Quevedo.

\begin{tabular}{|c|c|c|c|c|}
\hline Site & Rainfall (mm) & Temperature $\left({ }^{\circ} \mathrm{C}\right)$ & Sunshine $^{\mathrm{a}}(\mathrm{h})$ & Global radiation ${ }^{\mathrm{b}}\left(\mathrm{MJ} \mathrm{m}^{-2} \mathrm{~d}^{-1}\right)$ \\
\hline \multicolumn{5}{|l|}{ Quinindé (1973-2013) } \\
\hline 1st semester & 2221 & 26.4 & 569 & 12.6 \\
\hline Annual & 2764 & 25.9 & 969 & 11.7 \\
\hline \multicolumn{5}{|l|}{ Quevedo (1970-2011) } \\
\hline 1st semester & 1861 & 25.4 & 509 & \\
\hline Annual & 2166 & 24.9 & 879 & \\
\hline Standards for oil palm & $>2000 \mathrm{~mm} \mathrm{yr}^{-1}$ & 22-33 (min. max.) & $1825-2555 \mathrm{~h} \mathrm{yr}^{-1}$ & $15 \mathrm{MJ} \mathrm{m}^{-2} \mathrm{~d}^{-1}$ \\
\hline
\end{tabular}

(a) Sunshine measured with a Campbell Stokes recorder; (b) from Davis weather station 2011 to 2013 only. The standards for oil palm are from Corley and Tinker (2016).

$\mathrm{N}, \mathrm{P}, \mathrm{K}, \mathrm{Ca}, \mathrm{Mg}$ and $\mathrm{Cl}$ (Corley and Tinker, 2016). The samples were analysed at the CIRAD laboratory (Montpellier, France). To detect possible deficiencies, results were compared with optimum contents referred by Fairhurst et al. (2004) for mature oil palm. As $\mathrm{N}$ content is known to decrease with palm age, the optimum was defined by using the model set by Caliman et al. (1994): $\mathrm{N}_{\text {opt }}=3.192-0.059$ Age $+0.001 \mathrm{Age}^{2}$. In the same way, $\mathrm{P}$ content was examined in relation with $\mathrm{N}$ content using the well-known relation between $\mathrm{N}$ and $\mathrm{P}$ established by Caliman et al. (1994): $\mathrm{P}_{\text {opt }}=0.0487 \mathrm{~N}+0.039$.

\subsection{Fertiliser trials}

To assess the influence of mineral nutrition on the yellowing symptoms, we used two long-term fertilisation trials (SM2) carried out at Quinindé by PDA and CIRAD. Trial TT02 was conducted from 1978 to 1998 on a sandy soil developed on alluvial deposits, and trial TT08 from 1999 to 2013 on a soil formed from volcanic ash deposits with a loamy texture. The aim of both trials was to study the effects of N, P, $\mathrm{K}$ and $\mathrm{Mg}$ fertilisers on their contents in frond 17 (standard frond used for this type of measure) and on the yield of fresh fruit bunches (FFB). In both trials, yellowing symptoms appeared and were observed annually.

\subsection{Statistics}

Student's t test was used to differentiate the average nutrient leaflet content with or without yellowing symptoms (Tab. 2). ANOVA was completed with a Tukey test at the 5\% limit, to analyse the effect of the treatments in factorial trials TT02 and TT08.

\section{Results}

\subsection{Impact of El Niño on climate variables}

Outside El Niño events, rainfall and sunshine are unevenly distributed between the first and second semesters of the year (Tab. 1). Annual rainfall is theoretically non-limiting for oil palm but is marked by a long dry season from July to
November, when monthly averages do not exceed $100 \mathrm{~mm}$. Annual sunshine is under $1,000 \mathrm{~h} . \mathrm{yr}^{-1}$ and global radiation under $12 \mathrm{MJ} \mathrm{m}^{-2} \mathrm{day}^{-1}$.

FTSW calculated on La Concordia station data (SM3) shows that moderate water deficits could occur annually from August to December, with a more severe peak in November. However, this calculation was made using data from La Concordia weather station, where annual rainfall is only $1,400 \mathrm{~mm}$, i.e. conditions are much drier than at Quinindé $(2,764 \mathrm{~mm})$ or Quevedo $(2,166 \mathrm{~mm})$, so only very slight drought stress is expected at our study sites.

The 1982/1983 El Niño event started in August 1982 and lasted until November 1983. The 1997/1998 El Niño event started in April 1997 and lasted until July 1998. As shown in Figure 1, each El Niño event was characterized by an increase in rainfall and sunshine in relation with their average values outside the event. This led to a non-limiting and more regular annual distribution over the year, avoiding risks of sunshine limitation and drought spell.

A comparison of daily meteorological data from PDA station, with El Niño (July 1997 to June 1998) and without El Niño (mean July 2002 to June 2005), confirmed the favourable impact of El Niño on the climate variables influencing the oil palm physiology:

- the annual rainfall more than doubled (from 2,439 to $6,063 \mathrm{~mm})$;

- minimal and maximal temperatures increased by $2{ }^{\circ} \mathrm{C}$ (from 21.3 to $22.9^{\circ} \mathrm{C}$, and from 30.9 to $33.2^{\circ} \mathrm{C}$ respectively);

- insolation increased by $70 \%$ (from 854 to $1,464 \mathrm{~h}$ );

- the maximum climatic demand as measured by the VPD (Vapor Pressure Deficit) at noon, increased by 50\% (from 1.3 to $2.0 \mathrm{kPa})$.

\subsection{Variations in leaflet contents}

Mineral analysis in 2008 and 2009 (Tab. 2) showed that the yellowing leaflets had significantly lower $\mathrm{N}$ and $\mathrm{P}$ contents than healthy leaflets. $\mathrm{K}, \mathrm{Ca}, \mathrm{Mg}$ or $\mathrm{Cl}$ contents were not significantly or systematically lower in the yellowing tissues, 
B. Dubos and M. de Raïssac: Cah. Agric. 2021, 30, 34

Table 2. Nutrient contents (\%D.M.) in leaflets from fronds 12 to 17 with or without yellowing symptom.

Tableau 2. Teneurs en éléments nutritifs (\%D.M.) des folioles des feuilles 12 à 17, avec ou sans symptômes de jaunissement.

\begin{tabular}{|c|c|c|c|c|c|c|}
\hline Symptoms & $\mathrm{N}$ & $\mathrm{P}$ & $\mathrm{K}$ & $\mathrm{Ca}$ & $\mathrm{Mg}$ & $\mathrm{Cl}$ \\
\hline \multicolumn{7}{|c|}{2008 sampling } \\
\hline Without & 2.507 & 0.158 & 1.164 & 0.948 & 0.156 & 0.732 \\
\hline P-value & 0.000 & 0.001 & 0.013 & 0.013 & 0.600 & 0.198 \\
\hline \multicolumn{7}{|c|}{2009 sampling } \\
\hline Without & 1.946 & 0.130 & 1.618 & 0.720 & 0.115 & 0.922 \\
\hline P-value & 0.000 & 0.000 & 0.411 & 0.693 & 0.646 & 0.118 \\
\hline
\end{tabular}

In 2008, palms were 8 to 11 years old. The same palms were used for each sample, with or without symptoms with 5 replicates; in 2009 , palms were 11 to 12 years old. The same fronds from the same palms were used for each sample with or without symptoms with 6 replicates (PDA, Quinindé).

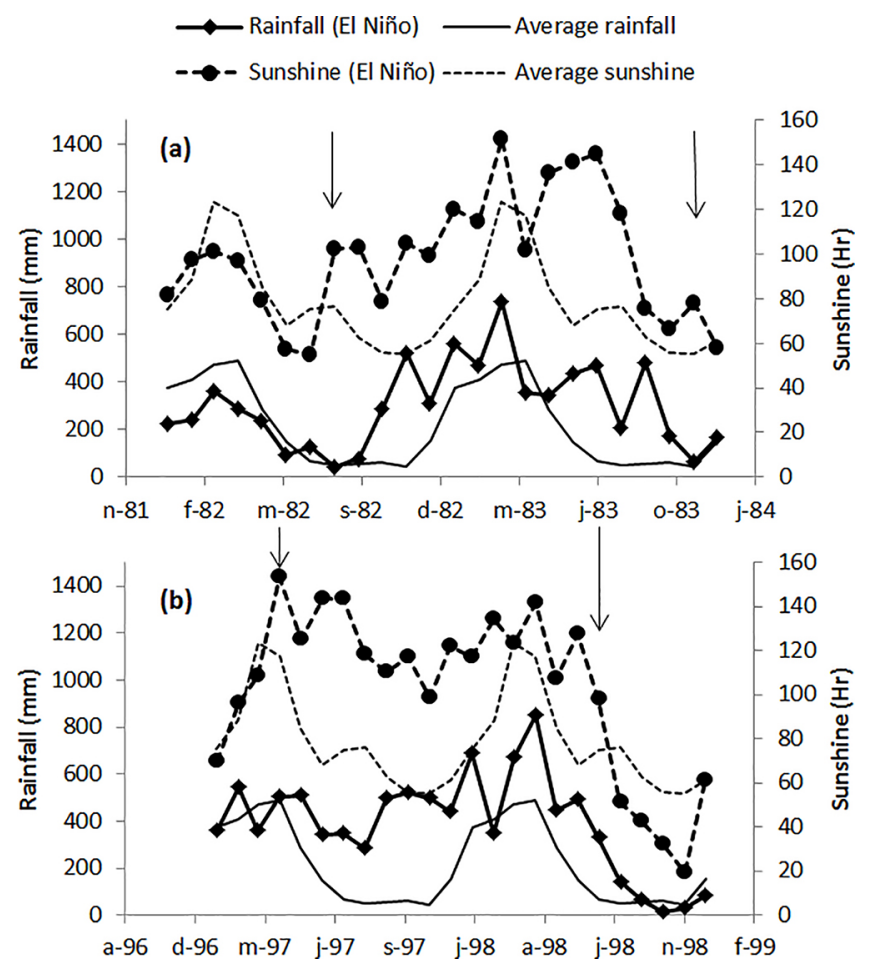

Fig. 1. Effects of El Niño 1982/1983 (a) and El Niño 1997/1998 (b) on monthly rainfall and sunshine compared with the monthly average value with La Niña event. Sunshine measured with a Campbell Stokes recorder. Arrows indicate the beginning and the end of El Niño at PDA, Quinindé.

Fig. 1. Effets de El Niño 1982/1983 (a) et El Niño 1997/1998 (b) sur les précipitations et l'ensoleillement mensuels comparés aux valeurs moyennes mensuelles avec La Niña. Ensoleillement mesuré avec un enregistreur Campbell Stokes. Les flèches indiquent le début et la fin d'El Niño à PDA, Quinindé.

thereby ruling them out as explanatory factors. $\mathrm{Mg}$ concentrations were generally low but independent from yellowing.

Fertilisation trials TT02 and TT08 were conducted over long periods and high fertiliser rates (SM2). The treatments had significant effects on $\mathrm{N}, \mathrm{P}, \mathrm{K}$, and $\mathrm{Cl}$ nutrition, but never led to a significant decline in yellowing symptoms. In particular, in trial TT02, magnesium fertiliser very significantly improved $\mathrm{Mg}$ content (Tab. 3) without any effect on yellowing symptoms. In both trials, $\mathrm{N}$ content also increased significantly with the nitrogen fertiliser, although to a limited extent, since the maximum increase did not exceed $5 \%$ in relation with control.

Surprisingly, during El Niño 1997/1998, in PDA plantations, leaflet $\mathrm{N}$ content suddenly increased with no additional application of fertiliser and yellowing disappeared. This increase was confirmed in trial TT02 (Fig. 2), where N content decreased with age up to 1996 before a sudden and significant increase at the end of 1997 and 1998. The variation was found in both the control without nitrogen fertilizer (N0) and the treatments in which nitrogen was supplied (N1 and N2).

\section{Discussion and prospects}

\subsection{Relations between leaflet contents and yellowing}

In the $1970 \mathrm{~s}$, many authors suspected a mineral deficiency to be the cause of the yellowing. Their opinion did not change after biotic hypotheses had been invalidated (Renard, 1977). For these experts as well as for Van Slobbe (1988), Mg was the nutrient most probably responsible, as $\mathrm{Mg}$ contents were frequently $<0.16-0.20 \%$, a range often considered as a deficiency level (Dubos et al., 1999). Corrado and Martinez Lopez (1982) also pointed to the generally low $\mathrm{N}$ contents compared with other locations where yellowing symptoms are not observed. However, long term fertiliser trials TT02 and TT08 failed to reveal a nutrient deficiency based on scarce soil reserves that could explain the symptoms. If this had been the case, the symptoms would have disappeared once the limiting nutrient was supplied. Trial TT02 confirmed that the low $\mathrm{Mg}$ contents could be significantly improved by $\mathrm{Mg}$ fertiliser applications but nevertheless had no effect on yellowing. Both trials also confirmed that $\mathrm{N}$ contents could be significantly improved by applications of $\mathrm{N}$ fertiliser, but again with no foliage recovery.

Conversely, in trial TT02, an improvement in foliage quality and $\mathrm{N}$ contents was observed at the same time as the 1997-1998 El Niño event. When this dramatic change 
Table 3. Effects of $\mathrm{Mg}$ and $\mathrm{N}$ fertilization on the average $\mathrm{Mg}$ and $\mathrm{N}$ contents of frond 17 in trials TT02 and TT08 at 10 to 17 years old and 10 to 15 years old palms, respectively.

Tableau 3. Effets de la fertilisation en $\mathrm{Mg}$ et en $\mathrm{N}$ sur les teneurs moyennes en $\mathrm{Mg}$ et en $\mathrm{N}$ de la feuille 17 dans les essais TT02 et TT08 respectivement de 10 à 17 ans et de 10 à 15 ans.

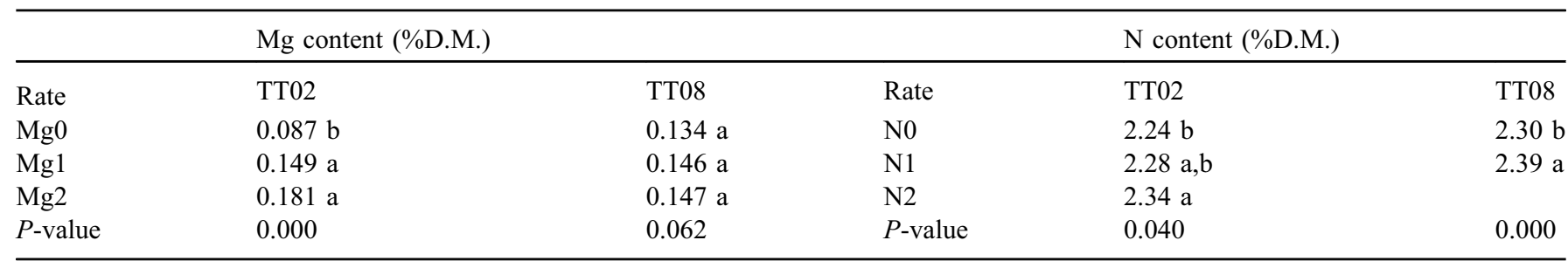

Average $\mathrm{Mg}$ fertilization rates were $0-60-120 \mathrm{~kg} \mathrm{MgO} \mathrm{ha}^{-1} \mathrm{yr}^{-1}$ for TT02 and 0-40-80 $\mathrm{MgO} \mathrm{ha}^{-1} \mathrm{yr}^{-1}$ for TT08. Average $\mathrm{N}$ fertilization rates were $0-60-150 \mathrm{~kg} \mathrm{~N} \mathrm{ha}^{-1} \mathrm{yr}^{-1}$ for TT02 and $0-200 \mathrm{~N} \mathrm{ha}^{-1} \mathrm{yr}^{-1}$ for TT08.

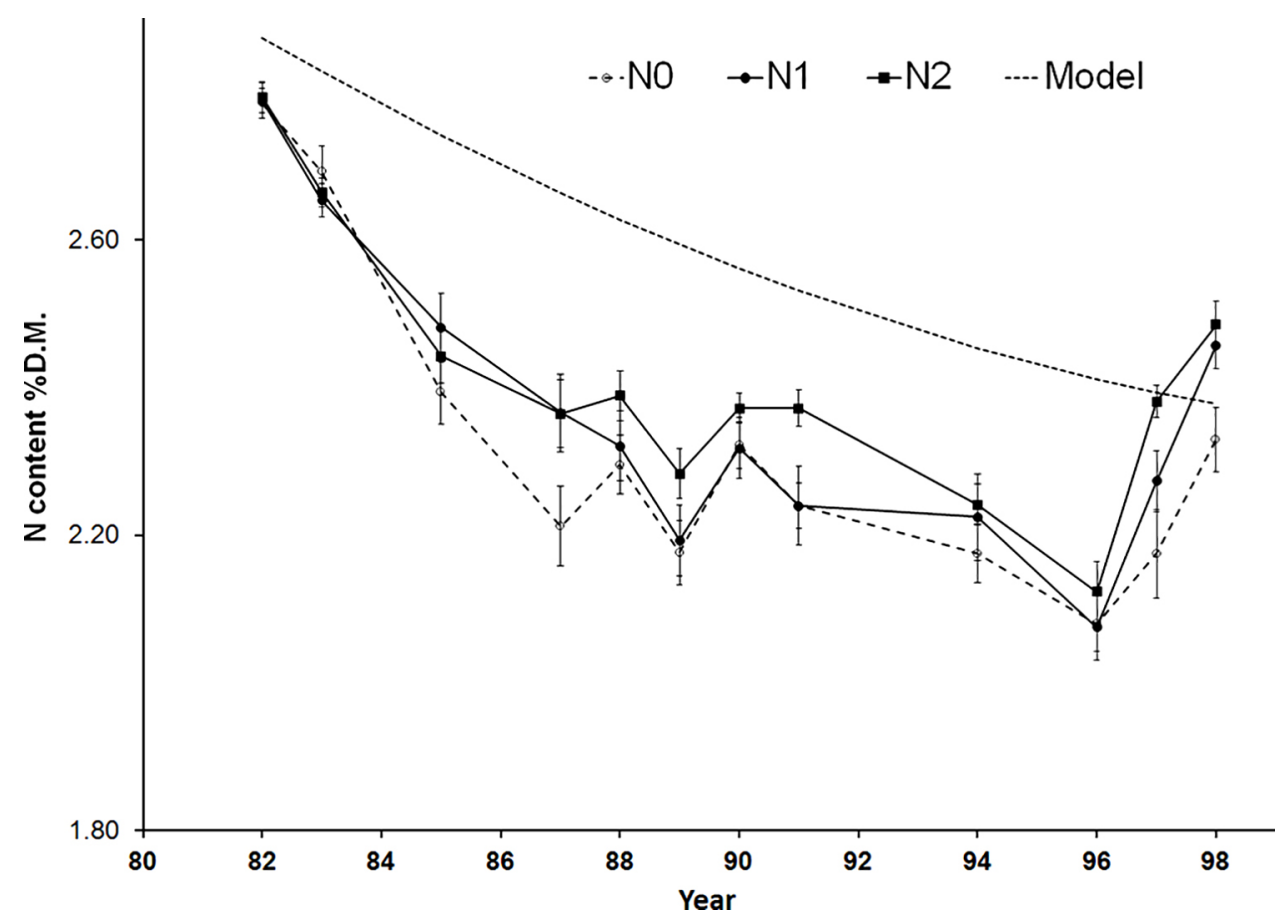

Fig. 2. Effect of El Niño 1997/1998 on $\mathrm{N}$ contents in frond 17 according to $\mathrm{N}$ fertilizer treatment in trial TT02 (N0: 0; N1: 60 and N2: $150 \mathrm{~kg} N$ $\mathrm{ha}^{-1} \mathrm{yr}^{-1}$ ). The model curve refers to the influence of age on optimum content: $\mathrm{N}=3.192-0.059$ Age +0.001 Age ${ }^{2}$. Average $\mathrm{N}$ contents increased from $87 \%$ in 1996 to $102 \%$ of the model in 1998 . Vertical lines represent the standard error.

Fig. 2. Effet de El Niño 1997/1998 sur les teneurs en N des feuilles 17 en fonction des apports de N dans l'essai TT02 (N0: 0; N1: 60 et N2: $\left.150 \mathrm{~kg} \mathrm{Nha}^{-1} \mathrm{an}^{-1}\right)$. La courbe modèle correspond à l'influence de l'âge sur la teneur optimale: $N=3.192-0.059$ Age +0.001 Age ${ }^{2}$. Les teneurs moyennes en $N$ ont augmenté de $87 \%$ en 1996 à $102 \%$ du modèle en 1998. Les lignes verticales représentent l'erreur standard.

occurred, $\mathrm{N}$ contents increased from $87 \%$ up to $102 \%$ of the model in 1996 and 1998 respectively. The climatic effect of El Niño was much greater than the effect of applications of $\mathrm{N}$ fertiliser on both $\mathrm{N}$ contents and disappearance of the symptoms.

We also observed that $\mathrm{N}$ and $\mathrm{P}$ contents were significantly and systematically lower in leaflets with yellowing symptoms (Tab. 2). The difference in $\mathrm{P}$ content was explained by a very constant relation with $\mathrm{N}$ contents (Caliman et al., 1994), but no yellowing symptoms have ever been found for a $\mathrm{P}$ deficiency. Finally, $\mathrm{N}$ contents appeared to be the best indicator of the presence or absence of yellowing, whereas there was no significant variation in $\mathrm{Mg}$ contents.
Although we rejected a direct $\mathrm{N}$ deficiency, i.e. due to soil $\mathrm{N}$ scarcity, this nutrient appeared to be the best indicator of yellowing, and variations in $\mathrm{N}$ status appeared to be linked to the same factors determining the symptoms.

\subsection{El Niño: a radical change in growing conditions, over a short but decisive time step}

With the climate changes triggered by El Niño in 1997/ 1998, some spectacular foliage recoveries were observed in the oil palm plantations in the region (Corrado, 1998). However, these beneficial effects did not last long, since Corrado (1999) 
reported that the yellowing symptoms reappeared in the plantations as early as June 1999. El Niño therefore underlies an effect that inhibits the cause of yellowing and that has never been reproduced experimentally. El Niño causes major climate changes in this part of Ecuador: the disappearance of the dry season in the second half of the year, a rise in temperature, a major increase in insolation and a consequent stimulation of the evaporative demand, phenomena that were clearly recorded by the EL 200 weather station near Quinindé during the two El Niño events (Fig. 1).

El Niño induces a dramatic improvement in annual sunshine and global radiation whose values are far below the required standards (i.e. $2,200 \mathrm{~h}_{\mathrm{yr}}{ }^{-1}$ and $15 \mathrm{MJ} \mathrm{m}^{-2} \mathrm{day}^{-1}$ respectively; Corley and Tinker, 2016). We hypothesised here that the disappearance of the dry season is not sufficient to explain the disappearance of the yellowing symptoms. Indeed no yellowing symptoms have ever been mentioned for drought stress in oil palm (Paramananthan, 2003). This type of yellowing is unknown under drier climatic conditions, as at the Pobè research station in Benin (West Africa), where average sunshine, $\left(1,750 \mathrm{~h} \mathrm{yr}^{-1}\right)$ is optimum for oil palm (Tab. 1), but average rainfall $\left(1,300 \mathrm{~mm} \mathrm{yr}^{-1}\right)$ is well below crop requirements (Corley and Tinker, 2016), and below that of the study region. Our hypothesis is also supported by the fact that, without El Niño, only slight water deficits are to be expected in Quinindé or Quevedo.

El Niño is also characterised by an average increase of 2 to $3^{\circ} \mathrm{C}$ in temperatures, which nonetheless remain close to optimum and cannot explain the change in plant performance. Even if cardinal temperatures (basal, optimum and maximum) are not determined in oil palm, Dufrêne (1989) observed in Ivory Coast a maintenance of the photosynthetic rate in the range from $30^{\circ} \mathrm{C}$ up to $38^{\circ} \mathrm{C}$, with a constant increase in the transpiration rate. In addition, the rise in temperature and solar radiation increased evaporative demand, maximum VPDs rising from 1.3 to $2.0 \mathrm{kPa}$, whereas the morning and evening values remained extremely low, at around 0.1 and $0.6 \mathrm{kPa}$, respectively. With El Niño, there is therefore a switch from a situation where the plant water flow is limited by the low climate demand to a situation where it is activated by higher VPD values. Even if oil palm starts regulating stomatal closure as early as VPD rises above $1.7 \mathrm{kPa}$ (Dufrêne and Saugier, 1993), the transient "noon depression" is more than compensated by the marked increase in carbon assimilation induced by the dramatic rise in solar radiation and water flow. In the study zone, sunshine is a major limiting factor, with annual means close to $2.5 \mathrm{~h} \mathrm{day}^{-1}$ (Tab. 1), which are well below the required 5 to $7 \mathrm{~h} \mathrm{day}^{-1}$. El Niño increased sunshine by more than $70 \%$, within a range where photosynthesis responds linearly to light (Dufrêne and Saugier, 1993). Conclusively with El Niño, changes in rainfall and temperature are of little effect on plant metabolism while changes in radiation and VPD caused a dramatic increase in carbon assimilation capacity, and hence, in growth.

\subsection{Hypotheses linked to the EI Niño effect}

Overall, we have seen that low leaf $\mathrm{N}$ and $\mathrm{Mg}$ contents cannot directly explain yellowing symptoms in oil palm. The hypothesis of a simple $\mathrm{Mg}$ deficiency can no longer be held as variations in $\mathrm{N}$ contents matched the presence and absence of symptoms. Nonetheless, the reason for the low $\mathrm{N}$ and $\mathrm{Mg}$ contents remains to be explained: are they linked or do they occur independently? Lastly, the El Niño event induced significant and rapid, beneficial, although reversible, changes in the N status of leaf tissues. The question is therefore how the disruptions caused by El Niño can transiently affect the metabolism of the plant and cause the symptoms to disappear. And what are the short term and reversible reactions of the palm to these climate fluctuations?

The marked increase in solar radiation and VPD are the only climatic factors consequently varying during El Niño and thus able to explain a change in leaf $\mathrm{N}$ status. We know that plant carbon assimilation is stimulated by high radiation and we found that the leaf $\mathrm{N}$ content increased correlatively. But the reason why a high level of $\mathrm{C}$ assimilation matches with a high $\mathrm{N}$ content, and the causal relationship between $\mathrm{C}$ and $\mathrm{N}$ metabolism, was out of the scope of the present study.

At the leaf level, it would be expected an increase of chlorophyll and $\mathrm{N}$ content with the low irradiance (Evans, 1989). Hence, the low leaf $N$ content observed in standard conditions highlights a limitation in $\mathrm{N}$ uptake rate, despite ample availability in the soil. Shall the root system be responsible? The quick and reversible change in $\mathrm{N}$ uptake with El Niño suggests a dysfunction in $\mathrm{N}$ uptake rather than a poor root development under normal conditions.

We hypothesize here that the low $\mathrm{N}$ demand by the frond metabolism drives the low $\mathrm{N}$ uptake by the roots. Nevertheless, since $\mathrm{N}$ uptake, as $\mathrm{P}$ or $\mathrm{K}$, is an active process requiring energy (Marschner, 1997; Mengel and Kirkby, 1987), we cannot discard its limitation by the low supply of assimilates by the shoot to the roots.

\section{Conclusions}

Our approach allowed us to rule out any deficiency in major nutrients as the cause of the yellowing found in the Quinindé to Quevedo oil palm zone. This conclusion is in agreement with the fact that the symptoms occur even though the soils in the region have varied textural and chemical properties. Our explanatory hypothesis is based on the changes that occur during El Niño events: improvement in gaseous exchanges due to increased solar radiation. The nutrient that characterises these changes is $\mathrm{N}$, enabling us to propose some hypotheses that can be tested experimentally. In particular, it would be useful to assess the organic and inorganic $\mathrm{N}$ contents of leaves, to analyse whether there is any upstream blockage in metabolic pathways. Due to the role of $\mathrm{Mg}$ in chlorophyll synthesis, the consequences for $\mathrm{Mg}$ nutrition need to be incorporated in a future research programme.

The resulting increase in our knowledge of the physiological dysfunctions in a normal situation should enable some headway to be made towards technical solutions for crop management. In other words, the mineral nutrition of palms depends on soil reserves and the prevailing climate. $\mathrm{N}$ and $\mathrm{Mg}$ foliar contents are influenced by climatic conditions and fertilization recommendations must take this into account as well as the distinction between the typical yellowing symptoms in the region and the true symptoms of magnesium deficiency. It will make it possible to avoid applying curative 
fertilisation when it is not justified and, conversely, preventing a true $\mathrm{Mg}$ deficiency from remaining uncorrected. The economic consequences of a misdiagnosis, involving all the oil palm plantations in the region, are all the more harmful in that most farms are under 50 ha in size and belong to smallholders. The environmental consequences of ill-advised applications of magnesium fertiliser should also be taken into account due to the imbalances they could induce between exchangeable cations in the soil and risks of excess nutrients being leached.

Our study also highlighted the specificity of the region in terms of $\mathrm{N}$ and $\mathrm{Mg}$ leaf contents and their sudden variations with the alternation between La Niña and El Niño. These alternations will be more frequent in the future, but in Ecuador, where $87 \%$ of the oil palm plantations are exposed to this phenomenon, the consequences will not be disastrous for the growers since El Niño generates climatic conditions favourable to yield development. However, it will be necessary to take these changes into account to accompany the growers in the management of the plantations, in particular with regard to fertilization and yield forecasting.

\section{Supplementary material}

The Supplementary Material is available at http://www. cahiersagricultures.fr/10.1051/cagri/2021021/olm.

SM1. Location of the oil palm area affected by yellowing symptoms in the western part of Ecuador. PDA (Palmeras de los Andes), Palmisa and Skinner are plantations where the symptoms were described.

SM2. Long-term nutrition trials at PDA, Quinindé.

SM3. Monthly rainfall, evaporation and soil water balance at the La Concordia station.

Acknowledgments. The authors would like to thank the Direction and the whole staff of PDA in Quininde for their support to the research program. We dedicate this article to the memory of the late Ing. Salomon Gutt. Our thanks also go to C. Fovet-Rabot for revising the manuscript.

\section{References}

Burgos R, Naranjo F. 2013. Ecuador País Palmicultor. Palma 20: 2030.

Cai W, Borlace S, Lengaigne M, Rensch P, Collins M, Vecchi G, et al. 2014. Increasing frequency of extreme El Niño events due to greenhouse warming. Nature Climate Change 4: 111-116. https:// doi.org/10.1038/NCLIMATE2100.

Caliman JP, Daniel C, Tailliez B. 1994. Oil palm mineral nutrition. Plantations, Recherche, Développement 1(3): 36-54.
Corley RHV, Tinker PB. 2016. The oil palm, 5th ed. Hoboken (USA): John Wiley \& Sons, 687 p. https://doi.org/10.1002/ 9781118953297.

Corrado F. 1998. Visita de Agronomía Palmisa ( ${ }^{\circ}$ CP1071). Montpellier (France): Cirad.

Corrado F. 1999. Visita de Agronomía Palmeras de los Andes ( ${ }^{\circ}$ CP1149). Montpellier (France): Cirad.

Corrado F, Martinez Lopez GM. 1982. El amarillamiento con secamiento de la palma africana en el Ecuador (Expertise). INIAP, ANCUPA, FAO.

Dubos B, Caliman JP, Corrado F, Quencez P, Siswo S, Tailliez B. 1999. Rôle de la nutrition en magnésium chez le palmier à huile. Plantations, Recherche, Développement 6(5): 313-325.

Dufrêne E. 1989. Photosynthèse, consommation en eau et modélisation de la production chez le palmier à huile. Thèse de doctorat. Centre d'Orsay: Université de Paris-Sud (France), 156 p.

Dufrêne E, Saugier B. 1993. Gas exchange of oil palm in relation to light, vapour pressure deficit, temperature and leaf age. Functional Ecology 7(1): 97-104. https://doi.org/10.2307/2389872.

Evans JR. 1989. Photosynthesis and nitrogen relationships in leaves of C3 plants. Oecologia 78(1): 9-19. https://doi.org/10.1007/ BF00377192.

Fairhurst T, Caliman JP, Hardter R, Witt C. 2004. Oil palm: nutrient disorders and nutrient management. Singapore: Potash \& Phosphate Institute, $125 \mathrm{p}$.

Marschner H. 1997. Mineral nutrition of higher plants, 2nd ed. (5. print). San Diego (USA): Academic Press, 889 p.

Mengel K, Kirkby EA. 1987. Principles of plant nutrition, 4th ed. Bern (Switzerland): Ed. International Potash Institute, $687 \mathrm{p}$.

Ministerio de Agricultura y Ganadería, FEDAPAL, ANCUPA, Aexpalma, APROGRACEC. 2018. Censo nacional palmero 2017 - Inventario de Plantaciones de Palma Aceitera en el Ecuador.

Nápoles VM. 1979. El amarillamiento de las plantaciones de palma africana en la zona de Santo Domingo de los Colorados. Ecuador: INIAP.

Paramananthan S. 2003. Land selection for oil palm. In: Fairhurst T, Hardter R, eds. Oil palm: management for large and sustainable yields. PPI, PPIC and IPI. Potash \& Phosphate Institute, pp. 307 320.

Renard JL. 1977. Informe de visita en las plantaciones de palma de aceite de la vía Quevedo ( $\left.{ }^{\circ} \mathrm{CP} 1347\right)$. IRHO.

Sinclair TR, Ludlow MM. 1986. Influence of soil water supply on the plant water balance of four tropical grain legumes. Functional Plant Biology 13(3): 329-341. https://doi.org/10.1071/PP9860329.

Timmermann A, Oberhuber A, Bacher M, Esch M, Roeckner E. 1999. Increased El Niño frequency in a climate model forced by future greenhouse warming. Nature 398: 694-697. https://doi.org/ $10.1038 / 19505$.

Van Slobbe WG. 1988. Amarillamiento, un trastorno de la palmera africana y algunos otros problemas fitosanitarios en el Ecuador Occidental. Amsterdam (Pays-Bas): HVA International BV.

Cite this article as: Dubos B, de Raïssac M. 2021. El Niño modifies nutrient status in oil palm and helps foliage to recover from yellowing symptoms: new analysis and perspectives. Cah. Agric. 30: 34. 